\title{
Current and Emerging Diseases/Disorders of Fish in Aquaculture
}

\section{Patrick TK Woo ${ }^{1 *}$ and Kenneth D Cain ${ }^{2}$}

${ }^{1}$ Department of Integrative Biology, University of Guelph, Canada

${ }^{2}$ Department of Fish and Wildlife Sciences, Aquaculture Research Institute, University of Idaho, USA

Animal protein is an essential component of a well-balanced diet and humans can get it from terrestrial and/or aquatic animals. Fish is relatively inexpensive and consequently it is an important source of animal protein for about 4.2 billion people. The catch-fishery is stagnant and according to some authorities it may actually be in decline. At present, about $50 \%$ of the fish for human consumption comes from aquaculture and this demand will escalate as the population increases. There are also numerous socio-economic benefits associated with the aquaculture industry; it not only provides direct and indirect employment, trade and manufacturing it also presents opportunities for stakeholders to develop specialized skills through training and education. Outbreaks of diseases and disorders are usually more prevalent with intensive aquaculture due to numerous factors which include enhanced transmission of pathogens between fish because of their close proximity to each other. Consequently, research and employment related to the detection and identification of pathogens, and the diagnosis, treatment and monitoring of infectious diseases/ disorders will increase in the future.
A significant amount of information on diseases/disorders has appeared since the publication (2006-2011) of the second edition of "Fish Diseases and Disorders, Volumes 1-3", CAB International, UK. The present special issue, "Current and Emerging Diseases/Disorders of Fish in Aquaculture" is mainly on recent research published since the publication of "Fish Diseases and Disorders" or on research not adequately covered in the triology because of page limitations. The current issue consists of six reviews written by 32 contributors from seven countries. Many of the contributors are highly respected scientists who had contributed significantly to research on fish diseases and disorders. The articles include studies on host-pathogen relationships of a bacterium and three parasites, and the physiological disorder and disease control of cortisol and heat shock proteins respectively.

We hope this special issue will be useful to colleagues interested in piscine diseases and disorders and also alert the aquaculture industry to emerging problems.
*Corresponding author: Patrick TK Woo, Department of Integrative Biology, University of Guelph, Canada, Tel: 519824 4120; Fax: 519767 1656; E-mail: pwoo@uoguelph.ca

Received August 26, 2013; Accepted August 27, 2013; Published August 28, 2013

Citation: Woo PTK, Cain KD (2013) Current and Emerging Diseases/Disorders of Fish in Aquaculture. J Aquac Res Development S2: e001. doi:10.4172/2155-9546. S2-e001

Copyright: @ 2013 Woo PTK, et al.This is an open-access article distributed under the terms of the Creative Commons Attribution License, which permits unrestricted use, distribution, and reproduction in any medium, provided the original author and source are credited. 